Kredo 3 (2020)
KREDO: Jurnal Ilmiah Bahasa dan Sastra
Terakreditasi Sinta 4 berdasarkan Keputusan Direktorat
Jenderal Penguatan Riset dan Pengembangan,
Kementerian Riset, Teknologi dan Pendidikan Tinggi
Republik Indonesia
Nomor: 23/E/KPT/2019. 08 Agustus 2019
https://jurnal.umk.ac.id/index.php/kredo/index

\title{
MODEL PENDIDIKAN KARAKTER BERBASIS KEUNGGULAN LOKAL DAN GLOBAL DI MAN PURWOREJO
}

\author{
Siti Khusniyati Sururiyah ${ }^{1}$, Cintya Nurika Irma ${ }^{2}$ \\ Email: khusniyati_nia77@yahoo.com¹, cintya_nurikairma@yahoo.co.id² \\ ${ }^{1}$ Prodi Pendidikan Agama Islam, Jurusan Tarbiyah, STAINU Purworejo \\ ${ }^{2}$ Prodi PBI, FKIP, Universitas Peradaban
}

Info Artikel Sejarah Artikel

Diterima 27

Desember 2019

Disetujui 24 Maret

2020

Dipublikasikan 29

April 2020

Keywords

character education,

local and global

excellence, students

Kata Kunci

pendidikan karakter,

keunggulan lokal dan

global, siswa

\section{Abstract}

: This study aims to describe and explain (1) the concept of educational unit level curriculum development in MAN Purworejo, (2) the character education model in lessons based on local and global excellence in MAN Purworejo, and the advantages and disadvantages of local and global excellence-based education in MAN Purworejo (3). This research is a qualitative research approach to humanistic educational psychology theory. Data collection techniques used interview techniques, passive participation observation techniques, and documentation techniques. The results showed that the character education model in MAN Purworejo can be seen from the values forming character education in local and global excellence-based learning in MAN Purworejo. First, learning by synergizing the values of religion, culture, and individual potential. Second, learning that educates

: knowledge that leads to hard skills and soft skills. Third, efforts need to be made to develop, change, improve the atmosphere of all positive school citizens by using core values of hard work, quality improvement, honesty, efficiency and democracy.

\begin{abstract}
Abstrak
: Penelitian ini bertujuan untuk mendeskripsikan dan menjelaskan (1) konsep pengembangan kurikulum tingkat satuan pendidikan di MAN Purworejo, (2) model pendidikan karakter dalam pembelajaran berbasis keunggulan lokal dan global di MAN Purworejo, dan (3) kelebihan dan kekurangan lokal dan global pendidikan berbasis keunggulan di MAN Purworejo. Penelitian ini adalah pendekatan penelitian kualitatif dengan teori psikologi pendidikan humanistik. Teknik pengumpulan data menggunakan teknik wawancara, teknik observasi partisipasi pasif, dan teknik dokumentasi. Hasil penelitian menunjukkan bahwa model pendidikan karakter di MAN Purworejo dapat dilihat dari nilai-nilai yang membentuk pendidikan karakter dalam pembelajaran berbasis keunggulan lokal dan global di MAN Purworejo. Pertama, belajar dengan menyinergikan nilai-nilai agama, budaya, dan potensi individu. Kedua, pembelajaran yang mendidik pengetahuan yang mengarah pada hard skill dan soft skill. Ketiga, upaya perlu dilakukan untuk mengembangkan, mengubah, meningkatkan atmosfer semua warga sekolah yang positif dengan menggunakan nilainilai inti dari kerja keras, peningkatan kualitas, kejujuran, efisiensi, dan demokrasi.
\end{abstract}




\section{PENDAHULUAN}

Orang-orang yang berkarakter kuat dan baik secara individual maupun sosial adalah mereka yang memiliki akhlak, moral, dan budi pekerti yang baik. Mengingat begitu pentingnya karakter, maka institusi pendidikan memiliki tanggung jawab untuk menanamkannya melalui proses pembelajaran yang berkarakter. Pendidikan karakter pada dasarnya berorientasi pada pendidikan peserta didik yang bermartabat dan berbudaya luhur. Setiap karakter yang dimiliki oleh semua orang dapat berubah, dan untuk mengubah karakter diperlukan pendidikan (Maksudin 2010:30). Sejatinya, pendidikan karakter merupakan bagian esensial yang menjadi tugas seluruh elemen dalam pendidikan, tetapi implementasinya masih mengalami beragam kendala dan perlu ada penanganan untuuk dilakukan tindak lanjut.

Implementasi berkarakter dalam satuan lembaga pendidikan perlu dilakukan secara berkelanjutan dengan melalui tiga model pembiasaan, yaitu: pembiasaan rutin, pembiasaan spontan, dan pembiasaan keteladanaan seperti yang tersurat dalam Kemendiknas (2011:48). Pertama, pembiasaan rutin dilakukan terjadwal, meliputi upacara bendera, senam, doa bersama, ketertiban, pemeliharaan kebersihan, dan kesehatan diri. Kedua, pembiasaan spontan merupakan kegiatan yang tidak terjadwal dalam kejadian khusus, meliputi pembentukan perilaku senyum, salam, sapa, membuang sampah pada tempatnya, budaya antri, mengatasi silang pendapat, saling mengingatkan ketika melihat pelanggaran tata tertib sekolah, kunjungan rumah, kesetiakawanan sosial, anjangsana.
Ketiga, pembiasaan keteladanan, yaitu kegiatan dalam bentuk perilaku sehari-hari, meliputi berpakaian rapi, berbahasa yang baik, rajin membaca, memuji kebaikan dan keberhasilan orang lain, datang tepat waktu. Penerapan ketiga pembiasaan tersebut secara langsung akan terpatri dalam diri guna merealisasikan pendidikan yang memiliki keunggulan secara lokal dan global. Sependapat dengan pernyataan Fatimah (2016:895) mengemukakan bila pengembangan nilai karakter dan keunggulan lokal melalui pembiasaan saja, sehingga tanpa dipaksakan, tetapi secara internalisasi akan melekat dalam kehidupan sehari-hari dan bangga dengan keunggulan lokal yang mereka miliki untuk dilestasikan dan regenerasi. Sejatinya, belajar harus dilakukan sepanjang hayat yang dibutuhkan dan diinginkan oleh tiap individu.

Selanjutnya, hasil wawancara dengan Kepala MAN Purworejo diketahui bila MAN Purworejo melakukan pengembangan kurikulum dengan mengacu pada UU RI Nomor 20 tahun 2003 pasal 50 ayat 5 berbunyi Sekolah Umum, Kejuruan maupun Madrasah diberikan kebebasan untuk mengadakan dan mengelola kurikulum yang terkait dengan pendidikan berbasis keunggulan lokal dan global untuk mengembangkan potensi peserta didik yang disesuaikan dengan potensi, perkembangan, kebutuhan dan kepentingan peserta didik serta tuntutan lingkungan. MAN Purworejo sebagai salah satu sekolah berciri khas Islam yang telah menerapkan pendidikan karakter dengan basis keunggulan lokal dan global yakni adanya implementasi pendidikan kecakapan hidup dalam proses pembelajaran. 


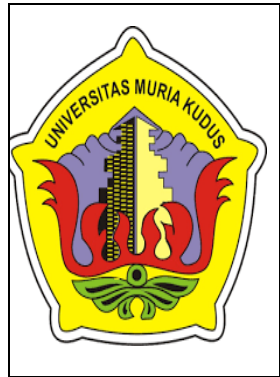

Kredo 3 (2020)

KREDO: Jurnal Ilmiah Bahasa dan Sastra

Terakreditasi Sinta 4 berdasarkan Keputusan Direktorat

Jenderal Penguatan Riset dan Pengembangan,

Kementerian Riset, Teknologi dan Pendidikan Tinggi

Republik Indonesia

Nomor: 23/E/KPT/2019. 08 Agustus 2019

https://jurnal.umk.ac.id/index.php/kredo/index

Implementasi pendidikan karakter yang berbasis nilai religius mengacu pada nilai-nilai dasar yang terdapat dalam agama (Islam). Nilai-nilai pendidikan karakter religius bersumber dari nilainilai keteladanan Rasulullah yang terjewantahkan dalam sikap dan perilaku sehari-hari beliau, yakni shiddiq (jujur), amanah (dipercaya), tabligh (menyampaikan dengan transparan), fathanah (cerdas) (Arsanti 2018:87). Aktuali nilai pendidikan karakter tersebut dapat dilakukan melalui proses memeriksa pemahaman dan mengintegrasikan pengetahuan yang dimiliki siswa. Huda (2018:30) menyatakan bila pembelajaran integrati merupakan seperangkat asumsi yang berisikan wawasan dan aktifitas berpikir dalam merencanakan pembelajaran dengan memadukan pengetahuan, pengalaman, dan keterampilan sebagai area pembelajaran.

Asmani (2012:43) menambahkan terdapat enam rambu-rambu yang harus diperhatikan dalam pelaksanaan pendidikan keunggulan lokal dan global. Pertama, sekolah yang mampu mengembangkan standar kompetensi dan kompetensi dasar beserta silabusnya dapat melaksanakan mata pelajaran keunggulan lokal dan global. Kedua, bahan kajian hendaknya sesuai dengan tingkat perkembangan peserta didik yang mencakup perkembangan pengetahuan dan cara berfikir, emosional, serta sosial peserta didik. Ketiga, program pengajaran hendaknya dikembangkan dengan melihat kedekatan dengan peserta didik. Keempat, bahan kajian/pelajaran hendaknya memberikan keluwesan bagi pendidik dalam memilih metode mengajar dan sumber belajar, seperti buku dan narasumber.
Kelima, bahan kajian keunggulan lokal dan global yang diajarkan harus bersifat utuh. Keenam, alokasi waktu untuk bahan kajian/pelajaran keunggulan lokal dan global perlu memperhatikan jumlah minggu efektif untuk mata pelajaran keunggulan lokal dan global pada setiap semester. Pendidikan sangat erat kaitannya dengan transformasi sosial sebab pendidikan juga bagian dari sistem sosial. Perbaikan pada sistem pendidikan perlu pengembangan yang lebih komprehensif agar pendidikan dapat menyentuh dan sinergi dengan dinamika sosial yang berlangsung. Penerapan pendidikan berkarakter yang unggul secara lokal dan global perlu diterapkan melalui proses konsep diri melalui implementasi pendidikan kecakapan hidup ke dalam mata pelajaran yang relevan. Terlebih saat ini pendidikan telah mengarah pada era revolusi 4.0.

Senada dengan penelitian yang dilakukan oleh Santoso (2010: 484) berjudul "Konsep Diri Melalui Pendidikan Berbasis Keunggulan Lokal Sebagai Model Pendidikan Berkarakter dan Berbudaya Bangsa di Era Global" disimpulkan bahwa model pendidikan berkarakter dan berbudaya dapat diimplemnetasikan dengan mangakomodasi keunggulan lokal di setiap daerah yang beragam dan khas baik fisik maupun non fisik. Strateginya dengan mengintegrasikan muatan keunggulan lokal pada aktivitas peserta didik yang diintegrasikan pada kultur sekolah. Secara bertahap dan berkelanjutan strategi tersebut dapat menumbuhkan motivasi intrinsik dan menjadi konsep diri yang berdasarkan interlocal wearness, terbuka dengan globalisasi, namun tetap beretika dan menjunjung potensi keunggulan lokal 
khasanah sekaligus sebagai identitas bangsa.

Keunggulan lokal dan global adalah segala sesuatu yang merupakan ciri khas kedaerahan yang mencakup aspek ekonomi, budaya, teknologi informasi dan komunikasi, ekologi, hasil bumi, kreasi seni, tradisi, budaya, pelayanan, jasa, sumber daya alam, sumber daya manusia, yang bermanfaat bagi pengembangan kompetensi peserta didik (Amri et. al 2011:1). Pendidikan dengan keunggulan lokal dan global merupakan paduan dari pengetahuan, keterampilan, kemandirian, dan kemampuan untuk menyesuaikan pendidikan dengan kondisi aktual di setiap daerah, sehingga mengarah pada pemecahan masalah yang dihadapi masyarakat setempat.

Selanjutnya, rumusan masalah dalam penelitian ini, yaitu: (1) bagaimanakah konsep pengembangan kurikulum di MAN Purworejo? dan (2) bagaimanakah model pendidikan karakter pada pelajaran yang berbasis keunggulan lokal dan global di MAN Purworejo? Tujuan penelitian ini sesuai dengan rumusan masalah yang telah dikemukakan yakni bertujuan untuk mendeskripsikankonsep pengembangan kurikulum di MAN Purworejo dan model pendidikan karakter pada pelajaran yang berbasis keunggulan lokal dan global di MAN Purworejo.

\section{KAJIAN TEORI}

\section{A. Pendidikan Karakter}

Pendidikan karakter sejatinya adalah nilai-nilai dasar yang harus dihayati oleh setiap individu di masyarakat agar dapat hidup berdampingan dan bekerjasama dengan damai. Ada beberapa nilai yang perlu diutamakan dalam penerapan pendidikan karakter, seperti nilai kebijaksanaan, penghormatan terhadap orang lain, tanggung jawab pribadi, perasaan senasib, dan pemecahan konflik secara damai. Lickona (1991:51) mengemukakan bahwa karakter memiliki tiga bagian yang saling berhubungan yakni: pengetahuan moral, perasaan moral dan perilaku moral. Pertama, pengetahuan moral terdiri dari kesadaran moral, mengetahui nilai-nilai moral, cara pandang, penalaran moral, pembuatan keputusan, dan pengenalan diri.

Kedua, perasaan moral terdiri dari hati nurani, harga diri, empati, mencintai kebaikan, pengendalian diri, dan kerendahan hati. Ketiga, tindakan moral terdiri dari kemampuan, kemauan dan kebiasaan. Hal ini selaras dengan paradigma berfikir tentang pembentukan karakter yang baik harus dimulai dari mengetahui kebaikan, kemudian ada hasrat menginginkan kebaikan dan dilanjutkan dengan melakukan kebaikan tersebut. Dalam rangka lebih memperkuat pelaksa-naan pendidikan karakter pada satuan pendidik-an, telah ditetapkan 18 nilai-nilai pembentuk karakter bangsa yang bersumber dari agama, pancasila, budaya, dan tujuan pendidikan nasional (Kementerian Pendidikan Nasional 2010: 9).

Menelaah dari pemikiran Presiden Joko Widodo dalam programnya Nawa Cita juga salah satunya memprioritaskan penguatan karakter. Yang mana di program Nawa Cita tersebut disebutkan bahwa pemerintah dalam hal ini (Kemndikbud) akan melakukan revolusi karakter bangsa. Implementasi penguatan karakter penerus bangsa tersebut dilaksanakan melalui gerakan Penguatan Pendidikan Karakter (PPK) yang digulirkan sejak tahun 2016 untuk mendorong agar pendidikan nasional 


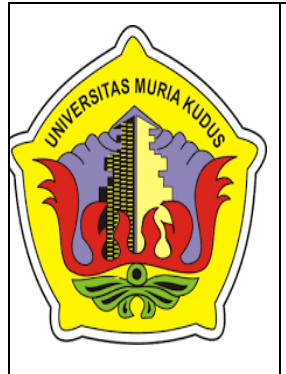

Kredo 3 (2020)

KREDO: Jurnal Ilmiah Bahasa dan Sastra

Terakreditasi Sinta 4 berdasarkan Keputusan Direktorat

Jenderal Penguatan Riset dan Pengembangan,

Kementerian Riset, Teknologi dan Pendidikan Tinggi

Republik Indonesia

Nomor: 23/E/KPT/2019. 08 Agustus 2019

https://jurnal.umk.ac.id/index.php/kredo/index

kembali memperhatikan olah pikir (literasi), olah hati (etik dan spiritual) olah rasa (estetik), dan juga olah raga (kinestetik).

Sementara

itu, pembelajaran intrakurikuler, kurikuler, dan ekstrakurikuler di sekolah dapat dilaksanakan dengan berbasis pada pengembangan budaya sekolah maupun melalui kolaborasi dengan komunitaskomunitas di luar lingkungan pendidikan. Terdapat lima nilai karakter utama yang bersumber dari Pancasila, yang menjadi prioritas pengembangan gerakan PPK tersebut yaitu religius, nasionalisme, integritas, kemandirian dan kegotong-royongan. Masing-masing nilai tidak berdiri dan berkembang sendiri-sendiri, melainkan saling berinteraksi satu sama lain, berkembang secara dinamis dan membentuk keutuhan pribadi.

Mengacu pada revisi Peraturan Pemerintah Nomor 74 Tahun 2008 menjadi PP Nomor 19 Tahun 2017, Kemendikbud mendorong perubahan paradigma para guru agar mampu melaksanakan perannya sebagai pendidik profesional yang tidak hanya mampu mencerdaskan anak didik, namun juga membentuk karakter positif mereka agar menjadi generasi emas Indonesia dengan kecakapan abad 21. Disinilah bisa dikatakan bahwa peran guru sangat penting dalam pendidikan, baik sebagai sosok yang mencerahkan, yang membuka alam dan pikir serta jiwa, memupuk nilai-nilai kasih sayang, nilainilai keteladanan, nilai-nilai perilaku, nilai-nilai moralitas, nilai-nilai kebhinnekaan, sehingga tidak berlebihan jika ada pernyataan mengatakan "kunci kesuksesan pendidikan karakter terletak pada peran guru".

190 | Jurnal Kredo

Vol. 3 No. 2 April 2020

\section{B. Pendidikan Berbasis Keunggulan Lokal dan Global}

Mengacu pada PP Nomor 25 Tahun 2000 tentang Otonomi Daerah yang mengatur pembagian kewenangan antara pemerintah pusat, pemerintah provinsi dan pemerintah kabupaten/kota, yang juga diperkuat dengan UU RI Nomor 22 Tahun 1999 tentang Pemerintah Pusat dan Daerah, maka otomatis ada perubahan politik dan tata pemerintahan yang semula bersifat sentralistik menjadi desentralistik. Adanya perubahan desentralisasi kebijakan itu, maka diharapkan daerah dapat mengembangkan potensi wilayahnya sesuai dengan situasi dan kondisi setempat.

Selanjutnya terkait pengembangan potensi daerah dalam hal pendidikan secara lebih luas mengacu pada UU RI Nomor 20 Tahun 2003 tentang Sistem Pendidikan Nasional, tepatnya BAB X pasal 37 ayat (1) yang menyatakan bahwa Kurikulum pendidikan dasar dan menengah wajib memuat Keterampilan/Kejuruan (butir i) dan muatan lokal (butir j). Sejak saat itulah maka muatan lokal yang disesuaikan dengan kebutuhan dan kekhasan dari masing-masing daerah diwajibkan masuk dalam kurikulum sekolah, baik di pendidikan dasar maupun pendidikan menengah.

Peraturan diatas juga diperkuat dengan mengacu pada UU RI Nomor 20 Tahun 2003 BAB XIV pasal 50 ayat (5) menyatakan bahwa Pemerintah Kabupaten/kota mengelola pendidikan dasar dan menengah, serta satuan pendidikan yang berbasis keunggulan lokal. Sejak saat itu maka masingmasing daerah mulai membuat kurikulum sekolah yang berbasis keunggulan lokal dan global. 


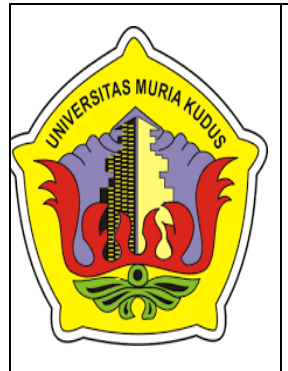

Kredo 3 (2020)

KREDO: Jurnal Ilmiah Bahasa dan Sastra

Terakreditasi Sinta 4 berdasarkan Keputusan Direktorat

Jenderal Penguatan Riset dan Pengembangan,

Kementerian Riset, Teknologi dan Pendidikan Tinggi

Republik Indonesia

Nomor: 23/E/KPT/2019. 08 Agustus 2019

https://jurnal.umk.ac.id/index.php/kredo/index

Sehubungan dengan kondisi daerah dan potensi daerah di Indonesia yang cukup beragam, maka masing-masing daerah perlu menggali, meningkatkan dan mempromosikan potensinya melalui pendidikan di sekolah dengan lebih baik lagi (Asmani 2012: 12).

Selanjutnya, mengacu pada PP 19 Tahun 2005 BAB III pasal 14 ayat (2) yang menyatakan bahwa pendidikan berbasis keunggulan lokal dapat merupakan bagian dari pendidikan kelompok mata pelajaran agama dan akhlak mulia, pendidikan kelompok mata pelajaran kewarganegaraan dan kepribadian, pendidikan kelompok mata pelajaran ilmu pengetahuan dan teknologi, pendidikan kelompok mata pelajaran estetika atau kelompok mata pelajaran pendidikan jasmani,olah raga dan kesehatan; serta diperkuat pasal 14 ayat (3) menyatakan bahwa pendidikan berbasis keunggulan lokal dapat diperoleh peserta didik dari satuan pendidikan yang bersangkutan atau dari satuan pendidikan nonformal yang sudah memperoleh akreditasi. Dari pemaparan peraturan diatas, sejatinya mata pelajaran yang berbasis keunggulan lokal dapat bermakna luas, disesuaikan dengan kebutuhan masing-masing daerah dengan kekhasan yang dimilikinya.

Agar sekolah dapat menarik masyarakat, maka terlebih dahulu harus dicari potensi yang ada dalam sekolah tersebut yang dapat dikembangkan yang memiliki daya saing berupa program unik yang dibutuhkan publik secara luas, mampu berjalan secara berkelanjutan dan tidak bisa ditiru oleh sekolah lain. Keunggulan lokal jika dikembangkan secara optimal sekiranya dapat menjadi keunggulan sekolah yang menarik masyarakat sekitar karena sekolah mampu mengubah sesuatu yang biasa di mata masyarakat menjadi sesuatu yang luar biasa akibat sentuhan sumber daya profesional dan teknologi tinggi. Oleh karena itu, sejatinya keunggulan lokal sebagai trade mark sekolah dapat yang dapat meningkatkan kesejahteraan, kemandirian, dan kemajuan bangsa secara keseluruhan dalam jangka panjang (Asmani 2012: 28).

\section{METODE PENELITIAN}

Jenis Penelitian ini adalah kualitatif deskriptif analitik dengan menggunakan pendekatan psikologi pendidikan humanistik. Penelitian dilakukan di MAN Purworejo dengan alamat Jl. Brigjen Katamso, Oangenjuru Tengah, Kabupaten Purworejo, Jawa Tengah 54114. Data diperoleh melalui observasi, wawancara, studi dokumentasi. Dalam menganalisis data yang digunakan melalui pendekatan analisis induktif, sedangkan pemeriksaan keabsahan data digunakan teknik triangulasi. Selain itu, reduksi data selalu dilakukan bila simpulan dirasa kurang.

\section{HASIL}

\section{A. Konsep Pengembangan Kurikulum di MAN Purworejo Madrasah Aliyah Negeri (MAN)} Purworejo sebagai salah satu sekolah berciri khas Islam dengan menerapkan pendidikan karakter dengan berbasis keunggulan lokal dan global melalui implementasi pendidikan kecakapan hidup dalam proses pembelajaran berbasis keunggulan lokal dan global unggulan madrasah ke dalam mata pelajaran yang relevan dan kegiatan kurikuler untuk mengembangkan kompetensi yang disesuaikan dengan ciri 


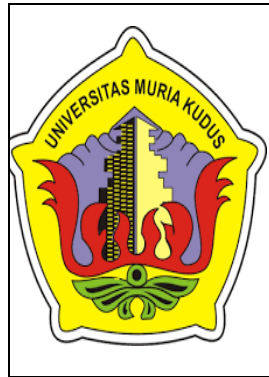

Kredo 3 (2020)

KREDO: Jurnal Ilmiah Bahasa dan Sastra

Terakreditasi Sinta 4 berdasarkan Keputusan Direktorat

Jenderal Penguatan Riset dan Pengembangan,

Kementerian Riset, Teknologi dan Pendidikan Tinggi

Republik Indonesia

Nomor: 23/E/KPT/2019. 08 Agustus 2019

https://jurnal.umk.ac.id/index.php/kredo/index

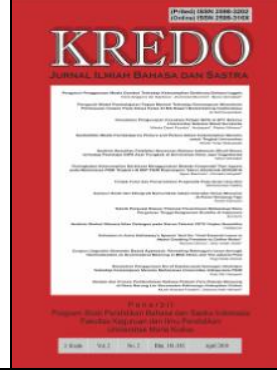

khas dan potensi keunggulan daerah Purworejo yang sesuai dengan kebutuhan masyarakat. Begitu pula dengan kegiatan pengembangan diri bertujuan memberikan kesempatan kepada peserta didik untuk mengembangkan dan mengekspresikan diri sesuai dengan kebutuhan, bakat, dan minat setiap peserta didik sesuai dengan kondisi sekolah.

Acuan yang digunakan dalam penyusunan kurikulum madrasah ini meliputi standar isi, standar kompetensi lulusan dan panduan penyusunan kurikulum madrasah dari Badan Standar Nasional Pendidikan (BSNP). Melalui Kurikulum Madrasah ini diharapkan pelaksanaan program-program pendidikan di MAN Purworejo sesuai dengan karakteristik potensi, dan kebutuhan peserta didik. Diantara mata pelajaran yang termasuk dalam pendidikan kecakapan hidup tersebut yakni tata busana, tata boga, dan bahasa Inggris interaktif, sedangkan untuk integrasi pendidikan berbasis keunggulan lokal dan global unggulan madrasah ke dalam mata pelajaran yang relevan dengan potensi keunggulan lokal dan kesiapan MAN Purworejo yakni qira'atul kutub, retorika dakwah, praktikum ibadah (fiqh ibadah), dan muhadlarah.

Adapun untuk kegiatan pengembangan diri unggulan madrasah yakni ekstrakurikuler kajian pendalaman agama dan qiro'ah (seni baca AlQur'an). Selanjutnya, salah satu strategi dari model pendidikan karakter berbasis keunggulan lokal di MAN Purworejo adalah menguatkan konsep diri peserta didik dengan interlocal awareness (keunggulan lokal), terutama konsep diri yang diarahkan pada proses pembiasaan berdasarkan prinsip keunggulan lokal yang nilainya diakui global seperti religius, tanggung jawab (responsibility), kemanusiaan, disiplin, kompetitif, bersih, dan sehat. Pada konteks ini, sinergi pengangkatan keunggulan fisik dan non fisik (nilai) keunggulan lokal sangat diperlukan.

\section{B. Implementasi Kurikulum Pendidikan Berbasis Keunggulan Lokal dan Global di MAN Purworejo \\ MAN Purworejo telah} merealisasikan pendidikan keunggulan lokal dan global sebagai program unggulan madrasah. Terobosan baru ini merupakan langkah progresif madrasah untuk menarik minat masyarakat terkait pembinaan dan pengembangan keagamaan maupun untuk memenuhi kebutuhan masyarakat akan sumber daya manusia yang kreatif dan produktif. Pada awal mulanya ide penambahan mata pelajaran pendidikan kecakapan hidup yang terintegrasi dalam muatan lokal dan pelajaran muatan lokal unggulan madrasah, berasal dari masukan masyarakat dan komite sekolah terkait kebutuhan masyarakat akan nilai-nilai religiositas dan jiwa kreatifitas yang semakin memudar.

Tahapan sebelum mengimplementasi pendidikan keunggulan lokalnya dengan melakukan identifikasi berbagai potensi keunggulan lokal dan menentukan skala prioritas potensi keunggulan lokal. Langkah ini efektif untuk merintis dan memaksimalkan pelaksanaan pendidikan berbasis keunggulan lokal dan global di sekolah dengan melibatkan banyak elemen supaya hasilnya memuaskan semua pihak. Menentukan skala prioritas penting supaya program ideal ini dapat terlaksana secara bertahap sesuai kekuatan internal sekolah, tidak tergesa- 


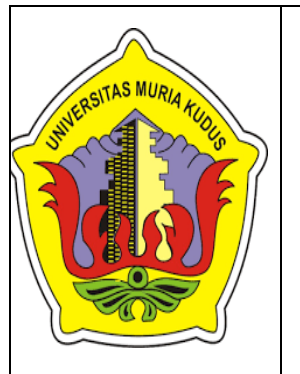

Kredo 3 (2020)

KREDO: Jurnal Ilmiah Bahasa dan Sastra

Terakreditasi Sinta 4 berdasarkan Keputusan Direktorat

Jenderal Penguatan Riset dan Pengembangan,

Kementerian Riset, Teknologi dan Pendidikan Tinggi

Republik Indonesia

Nomor: 23/E/KPT/2019. 08 Agustus 2019

https://jurnal.umk.ac.id/index.php/kredo/index

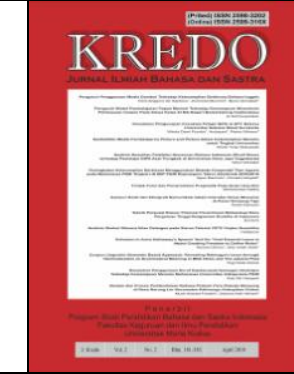

gesa, sehingga tidak mudah putus asa dan jatuh di tengah proses yang sedang berjalan.

Penerapan mata pelajaran muatan lokal di MAN Purworejo dilakukan mulai tahun pelajaran 2006/2007 seperti contohnya mata pelajaran retorika dakwah dan fiqh ibadah dahulunya menjadi satu pelajaran yang bernama keMAN-an, mata pelajaran qira'atul kutub dahulunya masih menjadi satu mata pelajaran dengan bahasa Arab, sedangkan mata pelajaran tata busana dahulunya masih menjadi kegiatan ekstra pengembangan diri, yakni ekstra menjahit. Penyusunan pengembangan kurikulum madrasah ini diharapkan sesuai dengan karakteristik potensi dan kebutuhan peserta didik. Selain itu, penyusunannya perlu melibatkan seluruh warga madrasah dan pemangku kepentingan lain (komite madrasah, orang tua peserta didik, masyarakat dan lembaga-lembaga lain).

\section{Model Pendidikan Karakter yang Terintegrasi Pada Pelajaran Berbasis Keunggulan Lokal dan Global di MAN Purworejo}

MAN Purworejo telah
merealisasikan pendidikan keunggulan lokal dan global sebagai program unggulan madrasah. Terobosan baru ini merupakan langkah progresif madrasah untuk menarik minat masyarakat terkait pembinaan dan pengembangan keagamaan maupun untuk memenuhi kebutuhan masyarakat akan sumber daya manusia yang kreatif dan produktif. Pada awal mulanya ide penambahan mata pelajaran pendidikan kecakapan hidup yang terintegrasi dalam muatan lokal dan pelajaran muatan lokal unggulan madrasah, berasal dari masukan masyarakat dan komite sekolah terkait kebutuhan masyarakat akan nilai-nilai religiositas dan jiwa kreatifitas yang semakin memudar.

Tahapan sebelum mengimplementasi pendidikan keunggulan lokalnya dengan melakukan identifikasi berbagai potensi keunggulan lokal dan menentukan skala prioritas potensi keunggulan lokal. Langkah ini efektif untuk merintis dan memaksimalkan pelaksanaan pendidikan berbasis keunggulan lokal dan global di sekolah dengan melibatkan banyak elemen supaya hasilnya memuaskan semua pihak. Menentukan skala prioritas penting supaya program ideal ini dapat terlaksana secara bertahap sesuai kekuatan internal sekolah, tidak tergesagesa, sehingga tidak mudah putus asa dan jatuh di tengah proses yang sedang berjalan.

Penerapan mata pelajaran muatan lokal di MAN Purworejo dilakukan seperti contohnya mata pelajaran retorika dakwah dan fiqh ibadah dahulunya menjadi satu pelajaran yang bernama ke-MAN-an, mata pelajaran qira'atul kutub dahulunya masih menjadi satu mata pelajaran dengan bahasa Arab, sedangkan mata pelajaran tata busana dahulunya masih menjadi kegiatan ekstra pengembangan diri, yakni ekstra menjahit. Penyusunan pengembangan kurikulum madrasah ini diharapkan sesuai dengan karakteristik potensi dan kebutuhan peserta didi dan penyusunannya melibatkan seluruh warga madrasah, komite madrasah, orang tua peserta didik, masyarakat, dan lembaga-lembaga lain. 


Kredo 3 (2020)
KREDO: Jurnal Ilmiah Bahasa dan Sastra
Terakreditasi Sinta 4 berdasarkan Keputusan Direktorat
Jenderal Penguatan Riset dan Pengembangan,
Kementerian Riset, Teknologi dan Pendidikan Tinggi
Republik Indonesia
Nomor: 23/E/KPT/2019. 08 Agustus 2019
https://jurnal.umk.ac.id/index.php/kredo/index

Tabel 1. Bentuk Integrasi Pendidikan Karakter dalam Kegiatan Intrakurikuler, Kurikuler, dan Ekstrakurikuler Berbasis Keunggulan Lokal dan Global di MAN Purworejo

\begin{tabular}{|c|c|c|}
\hline Model Pendidikan Karakter & Bentuk Sinergitas & $\begin{array}{l}\text { Implementasi Pendidikan Karakter } \\
\text { Berbasis Keunggulan Lokal dan Global } \\
\text { di MAN Purworejo }\end{array}$ \\
\hline \multirow[t]{3}{*}{ 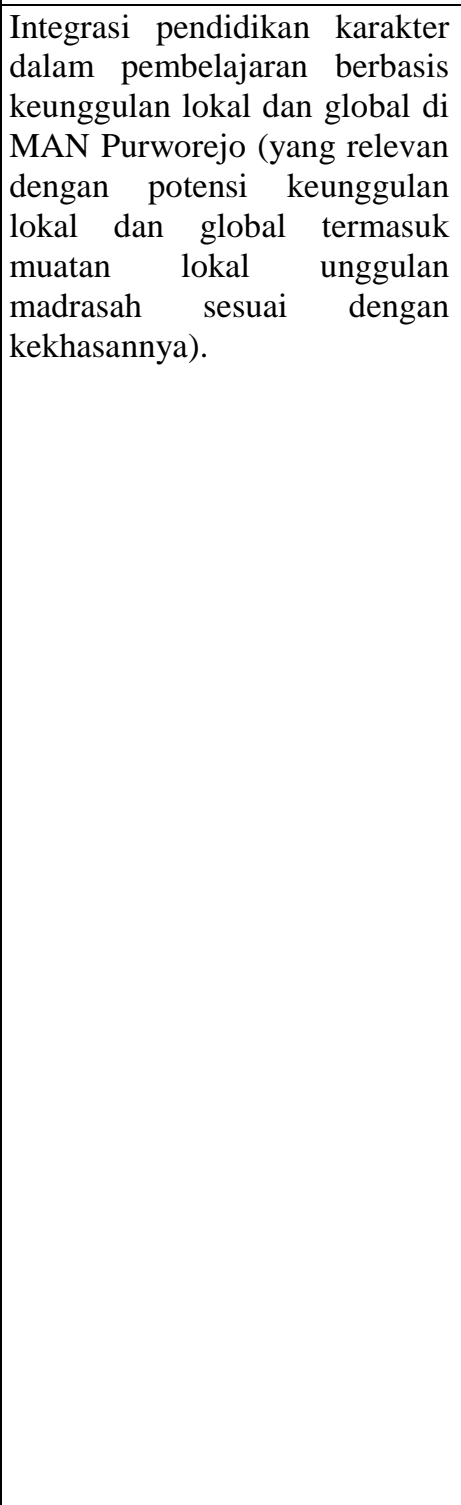 } & $\begin{array}{l}\text { Pembelajaran yang } \\
\text { memuat nilai agama, } \\
\text { kebudayaan, potensi } \\
\text { individual, serta } \\
\text { faktor lain }\end{array}$ & $\begin{array}{l}\text { a. Kegiatan intrakurikuler seperti: mata } \\
\text { pelajaran qira'atul kutub, retorika } \\
\text { dakwah dan fiqh ibadah. } \\
\text { b. Selain itu ada kegiatan kokurikuler } \\
\text { seperti: praktek kegiatan muhadlarah } \\
\text { Ramadhan (lomba hadrah/ kesenian } \\
\text { Islam, lomba Musabaqah Syahril } \\
\text { Qur'an (MSQ), lomba cerdas cermat } \\
\text { agama, lomba pembawa acara (MC) } \\
\text { dalam } 3 \text { bahasa (bahasa Inggris, } \\
\text { bahasa Indonesia dan bahasa Jawa), } \\
\text { lomba pidato } 3 \text { bahasa (bahasa Arab, } \\
\text { bahasa Inggris dan bahasa } \\
\text { Indonesia), dan lomba praktik fiqh } \\
\text { harian (perawatan jenazah, } \\
\text { ceremonial pernikahan, dan lain } \\
\text { sebagainya). }\end{array}$ \\
\hline & $\begin{array}{l}\text { 2. Pembelajaran yang } \\
\text { mendidik } \\
\text { pengetahuan, baik } \\
\text { hard skill maupun } \\
\text { soft skill }\end{array}$ & $\begin{array}{l}\text { a. Kegiatan intrakurikuler seperti : mata } \\
\text { pelajaran keterampilan tata busana, } \\
\text { keterampilan tata boga dan } \\
\text { Interactive English. } \\
\text { b. Selain itu ada kegiatan } \\
\text { ekstrakurikuler } \\
\text { ekstrakurikuler qiro'ah dan kajian } \\
\text { pendalaman agama. }\end{array}$ \\
\hline & \begin{tabular}{|l} 
3. Upaya \\
mengembangkan, \\
mengubah, \\
memperbaiki \\
atmosfir seluruh \\
warga sekolah yang \\
positif dengan \\
menggunakan core \\
values kerja keras, \\
peningkatan mutu, \\
jujur, efisien dan \\
demokratis.
\end{tabular} & $\begin{array}{l}\text { Tercantum dalam visi dan misi } \\
\text { madrasah yang } \\
\text { diimplementasikan dalam kegiatan } \\
\text { pembelajaran maupun kegiatan } \\
\text { ekstrakurikuler yang menekankan pada } \\
\text { praktik sehari-hari (membentuk sikap } \\
\text { saling menghargai, meningkatkan } \\
\text { iman dan takwa, menumbuhkan jiwa } \\
\text { kreatifitas dan kemandirian, semangat } \\
\text { dalam menuntut ilmu baik ilmu dunia } \\
\text { maupun ilmu akhirat. }\end{array}$ \\
\hline
\end{tabular}

Pendidikan karakter terdapat nilainilai luhur agama, kebangsaan, dan budaya menjadikan manusia mampu menempatkan dirinya sebagai sosok personal sekaligus sosial. Kecakapan personal mencakup kecakapan dalam memahami diri dan kecakapan berpikir. Adapun kecakapan sosial, mencakup kecakapan berkomunikasi dan kecakapan bekerja sama.. MAN 


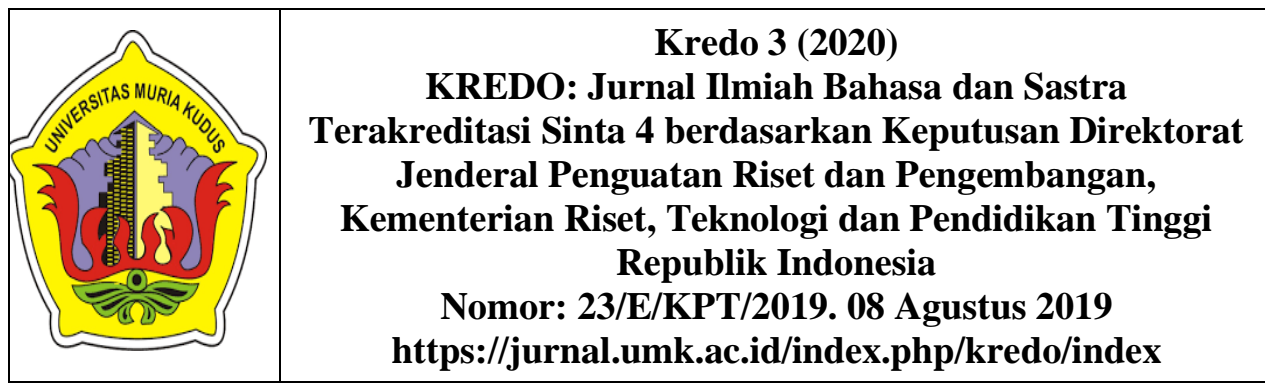

Purworejo telah menambahkan pendidikan kecakapan hidup melalui pendidikan berbasis keunggulan lokal dan global yang terintegrasi ke dalam mata pelajaran yang relevan untuk mengembangkan potensi peserta didik yang disesuaikan dengan potensi, perkembangan, kebutuhan, kepentingan peserta didik serta tuntutan lingkungan.

Wujud pendidikan karakter di MAN Purworejo yang terintegrasi di seluruh mata pelajaran, termasuk (muatan lokal) sesuai dengan kekhasannya, tercantum dalam masing-masing silabus pendidik ketika melakukan kegiatan pembelajaran. Hanya saja khusus untuk mata pelajaran keunggulan lokal dan global (seperti qira'atul kutub, retorika dakwah dan fiqh ibadah) memang tidak ada buku panduan dari pemerintah pusat, melainkan mencari sendiri buku acuannya dan pendidik juga menyusun sendiri materi-materinya. Kegiatan pengembangan diri pendidikan karakter diimplementasikan dalam (program bimbingan konseling dan kegiatan ekstrakurikuler). Sementara untuk kegiatan tidak terprogram pendidikan karakter dilakukan melalui (pembiasaan rutin, spontan dan keteladanan).

\section{PEMBAHASAN}

Pendidikan karakter yang berbasis keunggulan lokal dan global di MAN Purworejo dilakukan melalui pembelajaran sosial dan pembelajaran emosi yang dikembangkan melalui kurikulum dan pembiasaan. Pendidikan karakter juga dilakukan melalui pendekatan pembelajaran berbuat/ pembiasaan (action learning approach). Strategi pendidikan karakter diimplemetasikan pengembangan pengalaman belajar (learning experiences) dan proses pembelajaran yang bermuara pada pendidikan karakter peserta didik. Pengalaman belajar tersebut dibangun melalui intervensi dan habituasi. Pendidikan karakter merupakan upaya transformatif pengetahuan dan nilai dari nilai-nilai luhur yang bersumber dari agama, budaya, dan kebangsaan.

Pembelajaran nilai-nilai dan pendidikan karakter Islam yang dilaksanakan di MAN Purworejo selain berfokus pada akademik, akhlak, kemandirian juga berfokus pada dakwah Islam. Sosialisasi nilai dan karakter Islam disampaikan sebagai pengetahuan yang bersifat kognitif, afektif dan psikomotorik. Hal inilah yang akan menjadikan peserta didik maupun masyarakat tidak hanya termotivasi untuk mengenal Islam, tetapi juga berinisiatif secara mandiri untuk menggali nilai di balik ajaran agama Islam itu sendiri. Pendekatan Islam dengan kehidupan global melalui pendidikan karakter dapat berdampak guna memperbaiki dan memperbaharui pribadinya untuk menjadi khalifah dan insan kamil yang bertanggung jawab kepada Tuhan-Nya.

Pada akhirnya, pendidikan karakter bermuara kepada terwujudnya insan kamil yang bercirikan dua. Pertama, manusia yang seimbang, memiliki keterpaduan dua dimensi kepribadian (lahir dan batin). Kedua, manusia seimbang yang memiliki keseimbangan dalam kualitas pikir, dzikir dan amal saleh. Pengembangan mata pelajaran ditentukan pada fungsi dan susunan atau komposisi keunggulan lokal meliputi (a) 


Kredo 3 (2020)
KREDO: Jurnal Ilmiah Bahasa dan Sastra
Terakreditasi Sinta 4 berdasarkan Keputusan Direktorat
Jenderal Penguatan Riset dan Pengembangan,
Kementerian Riset, Teknologi dan Pendidikan Tinggi
Republik Indonesia
Nomor: 23/E/KPT/2019. 08 Agustus 2019
https://jurnal.umk.ac.id/index.php/kredo/index

melestarikan dan mengembangkan kebudayaan daerah,

meningkatkan keterampilan di bidang pekerjaan tertentu, (c) meningkatkan kemampuan berwiraswasta, dan (d) meningkatkan penguasaan bahasa asing. Selanjutnya, model pendidikan karakter perlu terintegrasi pada pelajaran berbasis keunggulan lokal dan global serta menumbuhkan kecakapan hidup.

Pendidikan kewirausahaan telah lama diimplementasikan di sekolah, baik secara khusus pada mata pelajaran kewirausahaan, juga terintegrasi pada mata pelajaran lain. Menanamkan nilainilai kewirausahaan pada diri siswa perlu dilakukan dengan berbagai cara, tidak hanya dilakukan secara formal di sekolah, juga di lingkungan masyarakat. Pendidikan kewirausahaan dapat dilaksanakan secara terpadu dalam proses pendidikan di sekolah dengan berbagai kegiatannya. Beberapa model pengintegrasian pendidikan kewirausahaan di sekolah dapat berbentuk: (a) pendidikan kewirausahaan termuat di dalam seluruh mata pelajaran, (b) pendidikann kewirausahaan termuat dalam kegiatan ekstra kurikuler, (c) pendidikan kewirausahaan dalam pengembangandiri, (d) pendidikan kewirausahaan yang mempraktikkan teori, (e) pendidikan kewirausahaan dalam buku dan bahan ajar, (f) pendidikan kewirausahaan melalui pembentukan budaya sekolah, dan (g) memasukkan pendidikan kewirausahaan ke dalam muatan lokal sekolah (Dewi, dkk., 2015).

\section{a. Bentuk Integrasi Pendidikan Karakter dalam Pembelajaran Berbasis Keunggulan Lokal dan Global di MAN Purworejo}

Upaya integrasi pendidikan karakter dalam pembangunan masyarakat masa depan yang memiliki daya saing dan mandiri perlu mensinergikan tiga hal. Pertama, nilai agama, kebudayaan, potensi individual serta faktor lain. Hal ini telah dilakukan oleh MAN Purworejo dengan mengintegrasikan pendidikan karakter dalam mata pelajaran yang relevan dengan potensi keunggulan lokal dan global termasuk muatan lokal unggulan madrasah sesuai dengan kekhasannya seperti mata pelajaran qira'atul kutub, retorika dakwah, fiqh ibadah dan muhadlarah. Kedua, pembelajaran yang mendidik pengetahuan, baik hard skill maupun soft skill. Hal ini telah terimplementasi di MAN Purworejo dalam kegiatan kurikuler pembelajaran.

Kegiatan tersebut termuat dalam pelajaran komponen umum, komponen agama, komponen pengembangan diri dan komponen muatan lokal (khususnya mata pelajaran keterampilan tata busana, keterampilan tata boga, interactive english, ekstrakurikuler qiro'ah, dan kajian pendalaman agama). Ketiga, perlu dilakukan upaya mengembangkan, mengubah, memperbaiki atmosfir seluruh warga sekolah yang positif dengan menggunakan core values kerja keras, peningkatan mutu, jujur, efisien, dan demokratis. Hal ini juga tercantum dalam visi dan misi madrasah yang sudah diimplementasikan dalam kegiatan pembelajaran maupun kegiatan ekstrakurikuler, yang lebih menekankan pada praktik sehari-hari. 


Kredo 3 (2020)
KREDO: Jurnal Ilmiah Bahasa dan Sastra
Terakreditasi Sinta 4 berdasarkan Keputusan Direktorat
Jenderal Penguatan Riset dan Pengembangan,
Kementerian Riset, Teknologi dan Pendidikan Tinggi
Republik Indonesia
Nomor: 23/E/KPT/2019. 08 Agustus 2019
https://jurnal.umk.ac.id/index.php/kredo/index

\section{b. Pendidikan Karakter dalam Menumbuhkan Kecakapan Hidup \\ Pendidikan karakter memiliki} kedekatan yang erat dengan kecakapan hidup manusia. Pelaksanaan pengembangan kurikulum tingkat satuan pendidikan di MAN Purworejo telah menambahkan pendidikan kecakapan hidup dalam pembelajaran, pendidikan berbasis keunggulan lokal dan global yang terintegrasi ke dalam mata pelajaran yang relevan dengan potensi keunggulan lokal dan global serta kesiapan pendidikan karakter MAN Purworejo yang terintegrasi di seluruh mata pelajaran termasuk muatan lokal sesuai dengan kekhasannya yang tercantum dalam masing-masing silabus pendidik. Berikut akan ditampilkan nilainilai pendidikan karakter dan indikatornya dalam mata pelajaran keunggulan lokal dan global di MAN Purworejo.

Pengertian kecakapan hidup memiliki kemampuan dasar pendukung secara fungsional seperti: membaca, menulis, dan berhitung, merumuskan serta memecahkan masalah, mengelola sumber daya, bekerja dalam kelompok, menggunakan teknologi (Departemen Pendidikan Nasional, 2002). Kecakapan hidup dapat dibagi menjadi dua jenis utama, yaitu: a) Kecakapan hidup generik (generic life skill/GLS), dan b) Kecakapan hidup spesifik (specific life skill/SLS). Masing-masing jenis kecakapan itu dapat dibagi menjadi sub kecakapan. Kecakapan hidup generik terdiri atas kecakapan personal (personal skill), dan kecakapan sosial (social skill). Kecakapan hidup spesifik adalah kecakapan untuk menghadapi pekerjaan atau keadaan tertentu. Kecakapan ini terdiri dari kecakapan akademik (academic skill) atau kecakapan intelektual, dan kecakapan vokasional (vocational skill) (Desmawati, dkk. 2017).

Tabel 2 Nilai-Nilai Pendidikan Karakter dan Indikatornya dalam Mata Pelajaran Keunggulan Lokal di MAN Purworejo

\begin{tabular}{|l|l|ll|}
\hline No & Nilai Karakter & \multicolumn{1}{c|}{ Indikator } \\
\hline 1. & Religius & 1) & $\begin{array}{l}\text { Peserta didik setiap mengawali dan mengakhiri pelajaran } \\
\text { selalu berdoa. }\end{array}$ \\
& & 2) $\begin{array}{l}\text { Peserta didik melaksanakan kegiatan salat zuhur berjamaah di } \\
\text { musala sekolah. }\end{array}$ \\
& 3) & $\begin{array}{l}\text { Peserta didik mempraktikkan hafalan juz amma dengan rutin } \\
\text { kepada pendidik bidang studi. }\end{array}$ \\
& 4) & $\begin{array}{l}\text { Peserta didik semakin bertambah iman dan takwanya dengan } \\
\text { mengetahui dalil dan sandaran hukum yang didapat dari } \\
\text { pelajaran fiqh ibadah maupun ekstra pendalaman kajian } \\
\text { agama. }\end{array}$ \\
\hline 2. & Jujur & 1) & $\begin{array}{l}\text { Peserta didik bertanya kepada pendidik ketika mendapati } \\
\text { materi pelajaran yang belum dipahaminya. } \\
\end{array}$ \\
& & 2) & $\begin{array}{l}\text { Peserta didik tidak membuka kamus Inggris ketika ulangan } \\
\text { sedang berlangsung. }\end{array}$ \\
\hline
\end{tabular}




Kredo 3 (2020)
KREDO: Jurnal Ilmiah Bahasa dan Sastra
Terakreditasi Sinta 4 berdasarkan Keputusan Direktorat
Jenderal Penguatan Riset dan Pengembangan,
Kementerian Riset, Teknologi dan Pendidikan Tinggi
Republik Indonesia
Nomor: 23/E/KPT/2019. 08 Agustus 2019
https://jurnal.umk.ac.id/index.php/kredo/index

\begin{tabular}{|c|c|c|c|}
\hline 3. & Toleransi & & $\begin{array}{l}\text { Peserta didik saling menghormati dan toleransi terhadap } \\
\text { teman yang berbeda madzhab ketika mengamalkan fiqh } \\
\text { ibadah dalam kehidupan sehari-hari }\end{array}$ \\
\hline 4. & Disiplin & 2) & $\begin{array}{l}\text { Peserta didik mengumpulkan semua tugas tertulis maupun } \\
\text { tugas praktik tepat waktu. } \\
\text { Peserta didik datang tepat waktu ke laboratorium bahasa } \\
\text { untuk mengikuti pelajaran Inggris Interaktif. }\end{array}$ \\
\hline 5. & Kerja Keras & 1) & $\begin{array}{l}\text { Peserta didik berusaha mengerjakan praktik tata boga dan tata } \\
\text { busana dengan baik dan kerja keras, meskipun itu hal yang } \\
\text { baru. } \\
\text { Peserta didik berusaha menghafalkan kosakata bahasa Inggris } \\
\text { sebanyak-banyaknya dalam mengikuti pelajaran Inggris } \\
\text { Interaktif. }\end{array}$ \\
\hline 6. & Kreatif & 1) & $\begin{array}{l}\text { Peserta didik mengkreasikan hasil pertanian menjadi makanan } \\
\text { ringan yang enak, menarik dan siap jual. } \\
\text { Peserta didik mengembangkan minat dan bakatnya dalam } \\
\text { bidang kesenian Islam, pidato dan pembawa acara (MC) } \\
\text { melalui kegiatan Muhadlarah Ramadhan. } \\
\text { Peserta didik mempraktikkan adegan pernikahan dalam } \\
\text { ceremonial Muhadlarah lengkap dengan kostum dan alat-alat } \\
\text { yang menunjang pertunjukan pernikahan seperti sungguhan. }\end{array}$ \\
\hline 7. & Mandiri & 1) & $\begin{array}{l}\text { Peserta didik belajar memproduksi makanan ringan dan } \\
\text { menjualnya, sehingga menghasilkan uang. } \\
\text { Peserta didik mampu menjahit sendiri pakaian/ rok/ celanan } \\
\text { seragamnya sekolahnya yang sobek. }\end{array}$ \\
\hline 8. & Demokratis & 1) & $\begin{array}{l}\text { Pendidik membagi kelompok diskusi ekstra pendalaman } \\
\text { kajian agama dengan adil. }\end{array}$ \\
\hline 9. & Rasa Ingin Tahu & 1) & $\begin{array}{l}\text { Peserta didik bertanya kepada pendidik ketika tidak } \\
\text { mengetahui makna dari kosakata bahasa Inggris. } \\
\text { Peserta didik bertanya kepada pendidik dan melakukan } \\
\text { eksperimen pengolahan hasil pertanian menjadi makanan } \\
\text { ringan yang sehat dan lezat. }\end{array}$ \\
\hline 11. & $\begin{array}{l}\text { Menghargai } \\
\text { Prestasi }\end{array}$ & 1) & $\begin{array}{l}\text { Peserta didik belajar dengan giat agar mendapat nilai ujian } \\
\text { yang memuaskan }\end{array}$ \\
\hline 12. & $\begin{array}{l}\text { Bersahabat/ } \\
\text { Komunikatif }\end{array}$ & 1) & $\begin{array}{l}\text { Peserta didik saling bekerjasama dalam kelompoknya ketika } \\
\text { praktik masak-memasak maupun dalam pelajaran tata busana. }\end{array}$ \\
\hline 13. & Cinta Damai & 1) & $\begin{array}{l}\text { Peserta didik saling menghargai hasil karya teman-temannya } \\
\text { dan tidak saling mengejek. }\end{array}$ \\
\hline 14. & Gemar Membaca & 1) & $\begin{array}{l}\text { Peserta didik mulai berlatih membaca teks maupun lagu yang } \\
\text { berbahasa Inggris dengan dipandu pendidik mata pelajaran } \\
\text { yang bersangkutan. }\end{array}$ \\
\hline 15. & $\begin{array}{l}\text { Peduli } \\
\text { Lingkungan }\end{array}$ & 1) & $\begin{array}{l}\text { Peserta didik membuang sampah bekas praktik memasak di } \\
\text { tempat sampah. }\end{array}$ \\
\hline 16. & Peduli Sosial & 1) & $\begin{array}{l}\text { Satu peserta didik dengan peserta didik yang lain saling bantu } \\
\text { membantu ketika praktik memproduksi makanan ringan. }\end{array}$ \\
\hline 17. & Tanggung Jawab & 1) & $\begin{array}{l}\text { Peserta didik yang ditunjuk jadi perwakilan kelas dalam } \\
\text { kegiatan Muhadlarah Ramadhan melaksanakan tugsa dengan } \\
\text { penuh tanggung jawab. }\end{array}$ \\
\hline
\end{tabular}

Hasil dari penelitian ini pelaksanaan model pendidikan karakter menunjukkan bahwa dengan adanya berbasis keunggulan lokal dan global di 


Kredo 3 (2020)
KREDO: Jurnal Ilmiah Bahasa dan Sastra
Terakreditasi Sinta 4 berdasarkan Keputusan Direktorat
Jenderal Penguatan Riset dan Pengembangan,
Kementerian Riset, Teknologi dan Pendidikan Tinggi
Republik Indonesia
Nomor: 23/E/KPT/2019. 08 Agustus 2019
https://jurnal.umk.ac.id/index.php/kredo/index

MAN Purworejo ini ditinjau dari berbagai aspek merupakan terobosan progresif dunia pendidikan dalam membangkitkan potensi daerah yang bermanfaat bagi masyarakat sekitar akan sumber daya manusia yang kreatif dan produktif. Keberhasilan tersebut karena didukung oleh beberapa keunggulan pendidikan berbasis keunggulan lokal dan global, diantaranya relevansi pendidikan dengan dunia nyata, membekali kompetensi spesifik peserta didik sebagai life skill, mendorong lahirnya kreatifitas, mendorong lahirnya entrepreneur profesional, dan mendorong kerjasama dengan masyarakat.

Kecakapan hidup (life skill) yang bersifat generik mencakup (1) kecakapan personal yang meliputi: (a) kesadaran eksistensi dan (b) kesadaran potensi diri, (2) kecakapan berpikir rasional meliputi: (a) kecakapan menggali, (b) kecakapan mengolah informasi, (c) kecapakan mengambil keputusan, dan (d) kecakapan memecahkan masalah, (3) kecakapan sosial meliputi: (a) kecakapan komunikasi lisan, (b) kecakapan komunikasi tertulis dan kecakapan bekerja sama (Handayani, 2009). Amiran (2012) menambahkan pengajaran pemecahan masalah, kesadaran diri, dan mengatasi keterampilan stres secara terpisah secara bersama-sama memiliki dampak pada tingkatan prestasi akademik siswa.

Kreatifitas akan muncul seiring dengan proses pembelajaran kecakapan hidup. Kini program kewirausahaan di sekolah sedang digaungkan guna menyiapkan diri siswa untuk berkompetensi dan memiliki kualitas untuk siap kerja. Program kewirausahaan yang seimbang setidaknya mengandung empat komponen: (a) membangun budaya entrepreneurial; (b) dukungan kebijakan yang mengawal terhadap pengadaan sumber daya, riset pasar, ruangan, dana awal, paten, konseling dan pendampingan, serta teknologi; (c) dukungan stakeholder seperti pemerintah, masyarakat, industry, jaringan alumni, dan praktisi; dan yang terpenting adalah (d) pengajar yang kompeten dan siap (Purnomo, 2015: 110).

Pendidikan karakter yang berbasis keunggulan lokal dan global di MAN Purworejo juga dilakukan melalui pembelajaran sosial dan pembelajaran emosi yang dikembangkan melalui kurikulum dan pembiasaan. Kurikulum merupakan suatu strategi pendekatan perkembangan kognitif sesuai perkembangannya. Hal ini dimaksudkan untuk mendorong peserta didik untuk berpikir aktif tentang masalah-masalah moral dan dalam membuat keputusankeputusan moral. Strategi pendidikan karakter diimplemetasikan dengan pengembangan pengalaman belajar dan proses pembelajaran yang bermuara pada pendidikan karakter peserta didik seperti tampak pada integrasi nilai-nilai karakter dalam pembelajaran retorika dakwah.

Tabel 3. Nilai Karakter dan Indikator Pada Pembelajaran Retorika Dakwah

\begin{tabular}{|c|c|lr|}
\hline No & $\begin{array}{c}\text { Nilai } \\
\text { Karakter }\end{array}$ & \multicolumn{2}{|c|}{ Indikator } \\
\hline 1. & Religius & $\begin{array}{l}\text { Peserta didik } \\
\text { bersemangat } \\
\text { mensyiarkan } \\
\text { Islam. }\end{array}$ & $\begin{array}{r}\text { untuk } \\
\text { dakwah }\end{array}$ \\
\hline
\end{tabular}




Kredo 3 (2020)
KREDO: Jurnal Ilmiah Bahasa dan Sastra
Terakreditasi Sinta 4 berdasarkan Keputusan Direktorat
Jenderal Penguatan Riset dan Pengembangan,
Kementerian Riset, Teknologi dan Pendidikan Tinggi
Republik Indonesia
Nomor: 23/E/KPT/2019. 08 Agustus 2019
https://jurnal.umk.ac.id/index.php/kredo/index

\begin{tabular}{|l|l|lr|}
\hline 2. & Toleransi & $\begin{array}{l}\text { Peserta didik belajar } \\
\text { untuk menghargai } \\
\text { temannya yang sedang } \\
\text { maju pidato di depan } \\
\text { kelas. }\end{array}$ \\
\hline 3. & Disiplin & $\begin{array}{l}\text { Peserta didik } \\
\text { mengumpulkan tugas } \\
\text { individu membuat naskah } \\
\text { pidato tepat pada } \\
\text { waktunya. }\end{array}$ \\
\hline 4. & Kerja keras & $\begin{array}{l}\text { Peserta didik berusaha } \\
\text { berlatih keras untuk } \\
\text { persiapan maju tugas } \\
\text { membawakan pidato dan } \\
\text { tugas menjadi MC acara } \\
\text { keagamaan di depan } \\
\text { kelas. }\end{array}$ \\
\hline 5. & Kreatif & $\begin{array}{l}\text { Peserta didik } \\
\text { menampilkan gaya } \\
\text { masing-masing agar } \\
\text { terlihat menarik ketika } \\
\text { mempraktikkan menjadi } \\
\text { da'i/da'iah. }\end{array}$ \\
\hline 6. & $\begin{array}{l}\text { Peserta didik menghargai } \\
\text { temannya dengan } \\
\text { bertepuk tangan setiap } \\
\text { kali teman-temannya telah } \\
\text { selesai memperagakan } \\
\text { pidato di depan kelas. }\end{array}$ \\
\hline
\end{tabular}

Pengalaman belajar tersebut dibangun melalui intervensi dan habituasi. Intervensi dalam pembelajaran dirancang dalam bentuk pembelajaran yang terstruktur di kelas. Habituasi diciptakan dalam kondisi yang memungkinkan peserta didik dimana saja membiasakan diri berperilaku sesuai dengan nilai dan telah menjadi karakter dirinya, karena telah terinternalisasi dan dipersonifikasikan melalui proses intervensi. Hasil penelitian Marton, dkk. (1997) mengungkapkan adanya korelasi antara "memperoleh", "mengetahui", dan "memanfaatkan". Keterkaitan lainnya juga terdapat tentang. kedalaman, mulai dari melihat belajar sebagai "melakukan kata-kata ke memori", "melakukan makna pada memori", "memahami makna" dan "memahami fenomena".

Proses aktivitas usaha siswa, kepercayaan kompetensi dan motivasi dari pengalaman belajar dalam masa sekolah dan mata pelajaran sekolah juga mempengaruhi dalam ketercapaian pembelajaran seperti yang dinyatakan oleh Malmberg and Andrew (2019). Adanya pengaruh perspektif proses dari pengalaman pengerahan upaya, keyakinan kompetensi, dan motivasi. Oleh karena itu perlu dilakukan interaksi antara guru dan siswa dengan memulai mematrikan minat dan motivasi, sehingga adanya peningkatan dalam usaha siswa memperbaiki dan meningkatkan kemampuan kompetensi yang dimiliki dalam diri terlebih tuntutan setelah siswa menuntaskan pembelajaran di sekolah dan bersiap diri mempraktikan apa yang diperoleh untuk diterapkan di lingkungan kerja dan masyarakat.

Peraturan dan tata tertib berfungsi sebagai alat untuk melakukan kontrol dalam proses pendidikan dan pengembangan karakter yang menjadi tujuan dengan meningkatkan disiplin. Rachman (2004: 35-36) berpendapat pentingnya membiaskan disiplin bagi siswa dengan tujuan (1) memberikan dukungan bagi terciptanya perilaku yang tidak menyimpang, (2) membantu siswa memahami dan menyesuaikan diri dengan tuntutan lingkungan, (3) cara menyelesaikan tuntutan yang ingin ditunjukan terhadap lingkungan, (4) mengatur keseimbangan keinginan individu satu dengan individu lainnya, (5) menjauhi siswa melakukan hal-hal yang dilarang disekolah, (6) mendorong siswa melakukan hal-hal yang baik dan 


Kredo 3 (2020)
KREDO: Jurnal Ilmiah Bahasa dan Sastra
Terakreditasi Sinta 4 berdasarkan Keputusan Direktorat
Jenderal Penguatan Riset dan Pengembangan,
Kementerian Riset, Teknologi dan Pendidikan Tinggi
Republik Indonesia
Nomor: 23/E/KPT/2019. 08 Agustus 2019
https://jurnal.umk.ac.id/index.php/kredo/index

benar. (7) belajar dan bermanfaat baginya dan lingkungarmya, dan (8) kebiasaan baik itu menyebabkan ketenangan jiwanya dan lingkungan.

Identifikasi, evaluasi, dan perbaikan perlu dilakukan bberlanjut termasuk dalam tindakan disiplin. Sanjaya (2006: 272-273) mengemukakan ada empat faktor yang merupakan dasar kepatuhan seseorang terhadap nilai tersebut. Pertama, normativist, biasanya kepatuhan pada norma-norma hukum. Selanjutnya dikatakan bahwa kepatuhan ini terdapat dalam tiga bentuk, yaitu : a. kepatuhan terhadap nilai atau norma itu sendiri, b. kepatuhan pada proses tanpa memperdulikan normanya sendiri, c. kepatuhan pada hasilnya/tujuan yang diharapkan dari peraturan itu. Kedua, integralis, yaitu kepatuhan didasarkan pada kesadaran. dengan pertimbangan pertimbangan yang rasional. Ketiga, fenomenalist, yaitu kepatuhan berdasarkan suara hati/sekedar basa-basi. Keempat, hedonist, yaitu kepatuhan berdasarkan kepentingan sendiri.

Pembelajaran nilai-nilai dan pendidikan karakter Islam yang dilaksanakan di MAN Purworejo selain berfokus pada akademik, akhlak, kemandirian, juga berfokus pada dakwah Islam. Selanjutnya, pendidikan karakter merupakan upaya transformatif pengetahuan dan nilai dari nilai-nilai luhur yang bersumber dari agama, budaya, dan kebangsaan dimulai dari segi materi, proses, dan penilaiannya, sehingga pendidikan karakter perlu didekatkan sebagai bagian dari nilai dan budaya generasi muda Indonesia agar menjadi pola sikap dan kultur dalam membangun peradaban bangsa secara lokal dan global. Lokal mengandung makna bahwa nilai-nilai Islam yang ditanamkannya mempunyai akar budaya dan tradisi tempat masyarakat tersebut tinggal. Global mengandung pengertian bahwa sikap dan perilaku yang diberikan kepada masyarakat, mampu menjawab tantangan yang diberikan masyarakat tersebut.

\section{SIMPULAN}

Implementasi kurikulum pendidikan berbasis keunggulan lokal dan global di MAN Purworejo dapat dilihat dari spesifikasi muatan kurikulum dan pengembangan mata pelajaran. Pendidikan karakter memiliki kedekatan yang erat dengan kecakapan hidup manusia. MAN Purworejo telah menambahkan pendidikan kecakapan hidup dalam pembelajaran yang terintegrasi ke dalam mata pelajaran yang relevan dengan potensi keunggulan lokal dan global, sehingga diharapkan kelak peserta didik memiliki kecakapan personal dan kecakapan sosial. Adapun implementasi pendidikan karakter dalam pembelajaran, yakni terintegrasi dalam beberapa mata pelajaran kecakapan hidup dan muatan lokal unggulan madrasah, seperti tata busana, tata boga, retorika dakwah, fiqh ibadah, qira'atul kutub, muhadlarah, dan interactive english.

Terkait kegiatan pengembangan diri terintegrasi dalam kegiatan ekstrakurikuler qiro'ah, dan kajian pendalaman agama. Selain itu, dilakukan dengan pembelajaran sosial dan pembelajaran emosi yang dikembangkan melalui kurikulum dan pembiasaan. Pendidikan berbasis keunggulan lokal 


Kredo 3 (2020)
KREDO: Jurnal Ilmiah Bahasa dan Sastra
Terakreditasi Sinta 4 berdasarkan Keputusan Direktorat
Jenderal Penguatan Riset dan Pengembangan,
Kementerian Riset, Teknologi dan Pendidikan Tinggi
Republik Indonesia
Nomor: 23/E/KPT/2019. 08 Agustus 2019
https://jurnal.umk.ac.id/index.php/kredo/index

dan global di MAN Purworejo, diantaranya sebagai berikut: relevansi pendidikan dengan dunia nyata, membekali kompetensi spesifik peserta didik sebagai life skill, mendorong lahirnya kreatifitas, mendorong lahirnya entrepeneur profesional dan mendorong kerjasama dengan masyarakat. Tentu hal ini juga mengarah pada penyiapan berkelanjutan pada aktualisasi pembelajaran revolusi society 5.0.

\section{DAFTAR PUSTAKA}

A., Doni Koesoema. 2007. Pendidikan Karakter Strategi Mendidik Anak di Zaman Global, Jakarta: Gramedia.

Amiran, K. 2012. "P-834-Effect of Life Skills Education on Academic Achievement of first Year High School Male Student". Journal European Psychiatry. Vol. 27 (1).

Amri, Sofian, dkk, 2011. Mengembangkan Pendidikan Berbasis Keunggulan Lokal. Jakarta: Prestasi Pustaka Raya.

Arsanti, Meilan. 2018. "Pengembangan Bahan Ajar Mata Kuliah Penulisan Kreatif Bermuatan Nila-Nilai Pendidikan Karakter Religius Bagi Mahasiswa Prodi PBSI, Fkip, Unissula". Jurnal Kredo. Vol. 1 (2).

Asmani, Jamal Ma'mur. 2012. Buku Panduan Internalisasi Pendidikan Karakter di Sekolah. Yogyakarta: Diva Press.

Departemen Pendidikan Nasional. 2002. Pola Pelaksanaan Pendidikan Berorientasi Kecakapan Hidup Melalui BBE untuk PMU. Jakarta: Tim Broad Based Education (BBE).

Desmawati, Liliek, dkk. 2017. Penerapan Model Pendidikan
Kecakapan Hidup pada Program Pendidikan Kesetaraan di Kota Semarang". Jurnal Edukasi, 2 (1).

Dewi, Laksmi, dkk. 2015. "Model Pendidikan Karakter dan Kewirausahaan Berbasis Etnopedagogis di Sekolah Dasar Kampung Cikondang". Jurnal Mimbar. Vol. 31 (2).

Fatimah. 2016. Pengembangan

Pendidikan Karakter dan

Keunggulan Lokal dalam

Kurikulum Kejuruan di SMK

Negeri Kabupaten Tapin. Jurnal Pendidikan Kewarganegaraan, 6 (11).

Handayani, Sri. 2009. “ Muatan Life Skills dalam Pembelajaran di Sekolah: Upaya Menciptakan Sumber Daya Manusia yang Bermutu". Dimuat dalam prosiding Konferensi Internasional Pendidikan, UPI- UPSI, Malaysia.

Huda, Miftakhul. 2018. "Strategi Berpikir Integratif dalam Pembelajaran Membaca Lintas Kurikulum di Sekolah Dasar". Jurnal Kredo. Vol. 1 (2).

Joko Susilo, Muhammad. 2008. Kurikulum Tingkat Satuan Pendidikan, Manajemen Pelaksanaan dan Kesiapan Sekolah Menyongsongnya. Yogyakarta: Pustaka Pelajar.

Kementerian Pendidikan Nasional. 2010. Bahan Pelatihan Penguatan Metodologi Pembel-ajaran Berdasarkan Nilai-nilai Budaya untuk Membentuk Daya Saing dan Karakter Bangsa. Jakarta: Kementerian Pendidikan Nasional. 


Kredo 3 (2020)
KREDO: Jurnal Ilmiah Bahasa dan Sastra
Terakreditasi Sinta 4 berdasarkan Keputusan Direktorat
Jenderal Penguatan Riset dan Pengembangan,
Kementerian Riset, Teknologi dan Pendidikan Tinggi
Republik Indonesia
Nomor: 23/E/KPT/2019. 08 Agustus 2019
https://jurnal.umk.ac.id/index.php/kredo/index

2011.

Panduan Pelaksanaan Pendidikan Karakter. Jakarta: Pusat Kurikulum dan Perbukuan Kemendiknas.

Lickona,Thomas. 1991. Educating for Character: How Our Schools Can Teach Respect and Responsibility. New York: A Bantam Book.

Maksudin. 2010. Pendidikan Islam Alternatif: Membangun Karakter Melalui Sistem Boarding School. Yogyakarta : UNY Press.

Marton, Ference, dkk. 1997. "Discontinuities and Continuites in the Experience of learning: An Interview Study of High-School Students in Hong Kong". Journal Learning and Instruction. Vol 7 (1).

Peraturan Pemerintah Republik Indonesia 19 Tahun 2005 Tentang Standar Nasional Pendidikan.

Peraturan Pemerintah Republik Indonesia Nomor 19 Tahun 2017 Perubahan atas Peraturan Pemerintah Republik Indonesia Nomor 74 Tahun 2008 tentang Guru.

Peraturan Pemerintah Republik Indonesia Nomor 25 Tahun 2000 Tentang Kewenangan Pemerintah dan Kewenangan Provinsi Sebagai Daerah Otonom.

Purnomo, Margo. 2015. "Dinamika Pendidikan Kewirausahaan:

Pemetaan Sistematis Terhadap

Pendidikan, Pengajaran, dan

Pembelajaran". Jurnal Dinamika

Manajemen. Vol. 6 (1).

Rachman, Natawijaya. 2003 Bimbingan

Kelompok: Jakarta: PT Bumi Aksara

Sanjaya, Wina. 2006. Strategi Pembelajaran Berorientasi Standar Proses

Pendidikan. Jakarta: Kencana

Santoso, Agus Muji. 2010. Konsep Diri

Melalui Pendidikan Berbasis

Keunggulan Lokal sebagai Model

Pendidikan Berkarakter dan

Berbudaya Bangsa di Era Global.

Proceedings of The 4th International

Conference on Teacher Education; Join Conference UPI \& UPSI, 477486.

Undang-Undang Republik Indonesia Nomor 20 Tahun 2003 Tentang Sistem Pendidikan Nasional.

Undang-Undang Republik Indonesia Nomor 22 Tahun 1999 Tentang Pemerintahan Daerah. 